\title{
APLIKASI PENGELOLAAN ASET PADA CSIS INDONESIA
}

\author{
Nuroji Lukmansyah ${ }^{1}$, Fauzan Natsir ${ }^{2}$, Sutrisno ${ }^{3}$ \\ 1,2,3 Teknik Informatika, Fakultas Teknik dan Ilmu Komputer, Universitas Indraprasta PGRI \\ Jalan Raya Tengah No. 80, Kelurahan Gedong, Pasar Rebo, Jakarta Timur \\ ${ }^{1}$ nurojilukmansyah@gmail.com, ${ }^{2}$ fauzan.natsir@gmail.com, ${ }^{3}$ sutrisno3831@gmail.com
}

\begin{abstract}
ABSTRAK
Centre for Strategic and International Studies Indonesia atau biasa disingkat menjadi CSIS Indonesia merupakan lembaga independen dan organisasi nirlaba yang berfokus pada isu-isu strategis baik itu dalam dan luar negeri. CSIS Indonesia didirikan pada tahun 1971 dengan fokus penelitian pada 3 bidang yaitu Ekonomi, Hubungan Internasional juga Politik dan Perubahan Sosial, selain 3 bidang tersebut saat ini ada dua unit penelitian lain yaitu Studi China dan Manajemen Bencana(CSIS, 2016). Sama seperti organisasi dan perusahaan lain, CSIS Indonesia juga mengharuskan setiap asetnya untuk dikelola, namun permasalahannya adalah, saat ini pencatatan aset hanya dilakukan oleh bagian keuangan, dimana aset hanya di catat di software akunting, dan tidak tercatatnya pergerakan aset. Dari persoalan tersebut peneliti tertarik untuk membuat sebuah aplikasi yang dapat mencatat pengelolaan aset, baik itu pengadaan, peminjaman dan pemindahan aset untuk membantu CSIS Indonesia dalam mengelola asetnya. Dengan menggunakan metode Grounded Research(Antony Bryant, 2017) peneliti menjalani proses seperti analisa perancangan sistem, studi kepustakaan dan studi literatur, pengumpulan data dan perancangan konsep, desain, pengujian sistem dan pembuatan laporan. Hasil dari penelitian ini akan memudahkan pengelolaan aset pada CSIS Indonesia.
\end{abstract}

Kata Kunci: Aplikasi, Pengelolaan aset, CSIS Indonesia,Android.

\begin{abstract}
Centre for Strategic and International Studies Indonesia-known as CSIS Indonesia-is an independent nonprofit organization specializing in strategic thinking and covering domestic and international issues. CSIS Indonesia was founded in 1971 and has consistently focused on three areas, namely Economics, International Relations, and Politics and Social Change. To accommodate the current trends, there are two additional research units, China Studies and Disaster Management(CSIS, 2016). Similar to other organizations or companies, CSIS Indonesia is also required to manage its assets. However, the responsibility to do asset management is solely given to the financial department, in which it is only recorded using the accounting software, without taking the asset flows into account. This lingering problem piqued the writer's interest in creating an application that can record asset management-whether it is asset procurement, loan, or transfer - to help CSIS Indonesia manage its assets. Utilizing the Grounded Research method(Antony Bryant, 2017), the writer went through the process of analyzing the systems, doing a desk study, collecting relevant data, designing the concept, testing the system, and finally, drafting the report. The result of this study is hoped to facilitate the management of assets at CSIS Indonesia.
\end{abstract}

Key Word: Application, Asset Management, CSIS Indonesia, Android.

\section{PENDAHULUAN}

Berdasarkan survei yang dilakukan oleh Statista pada tahun 2019 seperti dikutip dari website katadata yang menyatakan bahwa pengguna Ponsel Pintar di Indonesia sudah mencapai $28 \%$ dari penduduk Indonesia, artinya ada sekitar 74,76 juta jiwa dari 267 juta jiwa penduduk Indonesia sudah memiliki akses terhadap Ponsel Pintar, dalam laporan yang sama Statista memprediksikan pada tahun 2020 ada 30\% penduduk Indonesia sudah memiliki akses terhadap Ponsel Pintar.(Muchamad Nafi, 2019).

Hal tersebut juga mengindikasikan bahwa aplikasi mobile pada Ponsel Pintar memiliki peluang yang besar untuk berkembang, seiring semakin mudahnya akses pada Ponsel Pintar tersebut di Indonesia. Hal tersebut tercatat pada laporan App Annie tahun 2017, dalam laporannya yang berjudul App Annie 2017 Retrospective: A Monumental Year for The App Economy menjelaskan bahwa Indonesia merupakan salah satu pengguna aplikasi mobile paling aktif di dunia, setelah Korea Selatan yang berada di posisi ke-5 dan di bawah Brazil yang berada di posisi ke3.(App Annie, 2017).

Centre for Strategic and International Studies atau yang lebih dikenal dengan CSIS Indonesia merupakan sebuah lembaga penelitian yang didirikan pada 1 September 1971, dengan fungsi memberikan masukan 
kepada pembuat kebijakan dan fokus penelitian pada Ekonomi, Hubungan Internasional, Politik dan perubahan sosial juga Manajemen bencana.(CSIS, 2016).

CSIS Indonesia juga sama seperti organisasi lainnya yaitu melakukan pekerjaan administratif yang di dalamnya terdapat pencatatan dan pengelolaan aset. Aset sendiri merupakan suatu bentuk sumber daya ataupun alokasi dana (investasi) perusahaan.(David Wijaya, 2017).

Aset-aset tersebut dikumpulkan menjadi sebuah data, data dari aset-aset tersebut tersimpan pada sebuah program akuntansi yang di dalam penggunannya masih memiliki kendala, yaitu progam akuntansi tersebut merupakan program komputer untuk sistem Operasi berbasis Windows yang hanya mencatat pembelian dan penyusutan atau penghapusan aset. Untuk setiap pencatatan pengadaan dan peminjaman aset misalnya, mengharuskan user untuk melakukan pencatatan pada sebuah formulir untuk kemudian di-input secara manual.

Pada penelitian sebelumnya yang dilakukan oleh Adi Ahmad dan Riyan Maulana pada PT.Acehlink Media, Aplikasi Manajemen Aset yang menghasilkan sebuah kesimpulan bahwa aplikasi manajemen asset berbasis android akan lebih mudah diakses oleh pengguna sehingga dapat memfasilitasi petugas untuk mengawasi aset.(Ahmad \& Maulana, 2020).

Berdasarkan hal tersebut penulis berinisiatif untuk membuat sebuah aplikasi berbasis android yang dapat memenuhi kebutuhan pengelolaan aset pada CSIS Indonesia.

\section{METODE PENELITIAN}

Metode penelitian yang digunakan oleh peneliti adalah Metode Grounded. Merupakan metode riset kualitatif yang menggunakan suatu set prosedur yang sistematik untuk mengembangkan suatu teori secara induktif tentang suatu fenomena. Metode ini dimulai dari suatu pernyataan yang masih kabur dan akhirnya menghasilkan teori yang dikumpulkan dari berbagai data. (Antony Bryant, 2017)
Penelitian dilakukan di kantor CSIS Indonesia, CSIS Indonesia merupakan sebuah Lembaga penelitian yang berfokus pada pembuat kebijakan dengan fokus penelitian pada Ekonomi, Hubungan Internasional, Politik dan perubahan sosial juga Manajemen bencana, CSIS Indonesia sendiri beralamat di Gedung Pakarti Centre jalan Tanah Abang 3 No. 23-27, Jakarta Pusat.

Pada CSIS Indonesia, penulis memulai penelitian dengan melihat secara langsung bagaimana CSIS Indonesia melakukan pengelolaan aset, mulai dari pencatatan pengadaan barang, peminjaman barang dan penghapusan barang yang sudah mengalami penyusutan.(Ikatan Akuntan Indonesia, 2011), setelah itu penulis melakukan wawancara terhadap bagian-bagian yang bertanggung jawab dalam pengelolaan aset pada CSIS Indonesia, dari hasil observasi dan wawancara tersebut kemudian penulis merumuskan desain aplikasi yang cocok untuk diterapkan pada CSIS Indonesia.

\section{Metode Pengumpulan Data}

Studi Kepustakaan, data yang didapatkan berupa data sekunder. Peneliti mempelajari buku-buku yang ada pada perpustakaan CSIS Indonesia, selain itu penulis juga mencari sumber lain lewat jurnal-jurnal dan e-book mengenai pengelolaan aset.

Metode Lapangan, peneliti secara langsung mengumpulkan data menggunakan metode fact finding techniques yaitu proses formal menggunakan teknik seperti wawancara, dan daftar pertanyaan untuk mengumpulkan fakta tentang sistem, kebutuhan dan pilihan.(Indrajani, 2011). Metode tersebut berhubungan dengan sistem pengelolaan aset pada CSIS Indonesia. Data tersebut peneliti kumpulkan dengan cara:

a. Observasi dimana peneliti mengamati secara langsung proses pengelolaan aset yang dilakukan oleh CSIS Indonesia.

b. Wawancara dimana peneliti menyiapkan pertanyaan kepada karyawan mengenai bagaimana sistem pengelolaan aset pada CSIS Indonesia.

c. Dokumentasi dimana peneliti melakukan pengumpulan data dengan mencatat data yang ada pada dokumen atau arsip CSIS Indonesia. 


\section{HASIL DAN PEMBAHASAN}

\section{Analisa Permasalahan}

Setelah menganalisa sistem yang berjalan, peneliti menyimpulkan bahwa untuk mempermudah seluruh pengelolaan aset mulai dari pengadaan, peminjaman dan penghapusan aset, maka peneliti membuat sebuah Aplikasi Android pada CSIS Indonesia.

\section{Normalisasi}

Normalisasi adalah proses pengelompokan data kedalam bentuk tabel atau relasi atau file untuk menyatakan entitas dan hubungan sehingga terwujud satu bentuk database yang mudah untuk dimodifikasi, ada beberapa bentuk normalisasi.(Al- Bahra Bin Ladjamudin, 2013)

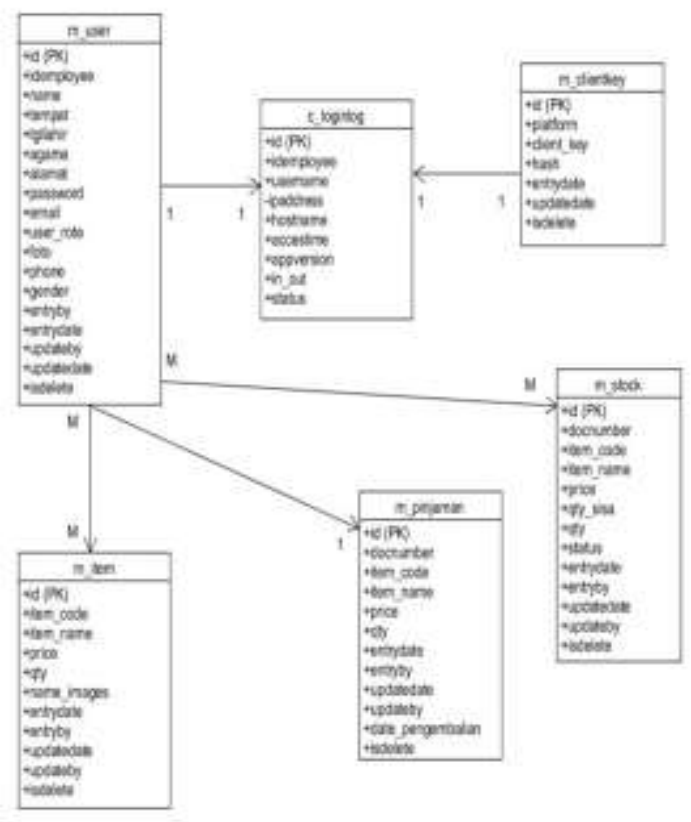

Gambar 1. Normalisasi

\section{Tampilan Aplikasi}

Aplikasi yang dibuat untuk kepentingan penelitian ini merupakan Aplikasi Android berbasis Flutter. Flutter sendiri merupakan aplikasi sumber terbuka yang dikembangkan oleh Google pada tahun 2015, kelebihan Flutter yaitu pengguna dapat membuat aplikasi yang dapat berjalan pada Android, iOS dan Google Fuchsia.(Carmine Zaccagnino, 2020).

Berikut ini gambar rekaman layar dari Aplikasi pengelolaan aset di CSIS Indonesia.

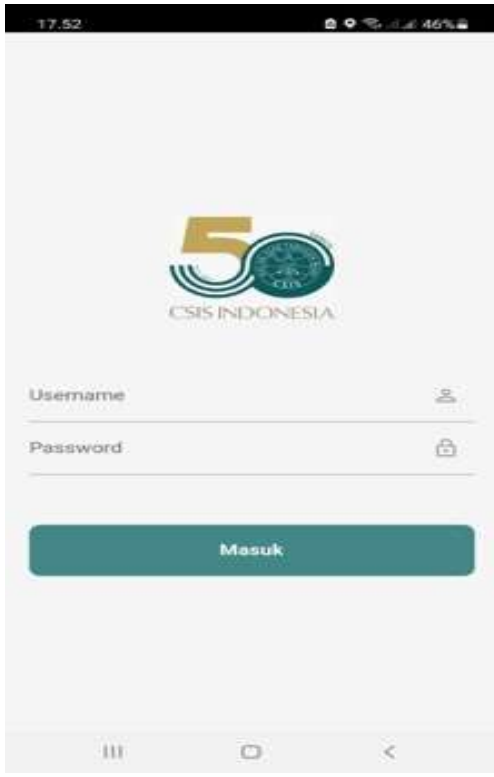

Gambar 2. Tampilan menu Login

Pada gambar 2 di atas menampilkan form untuk halaman login, halaman ini merupakan halaman awal dari aplikasi yang penulis buat, memiliki fungsi untuk membatasi akses kepada user berdasarkan kebutuhannya.

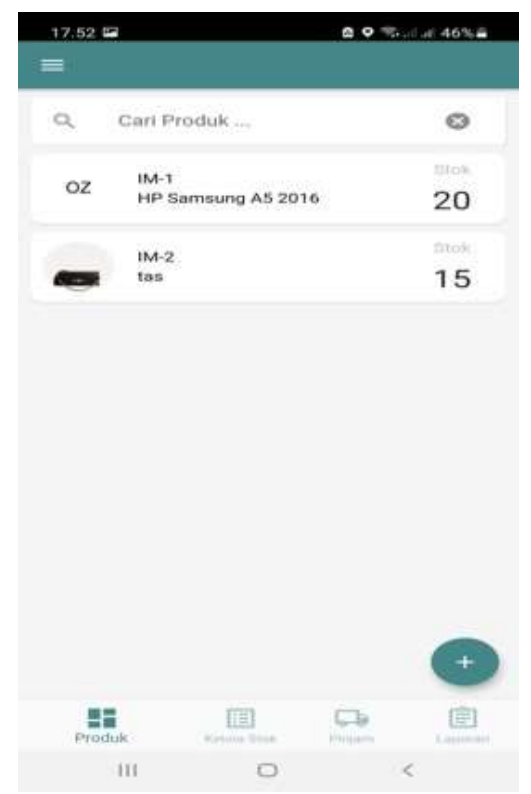

Gambar 3. Tampilan menu Daftar Produk

Tampilan di atas merupakan halaman yang menampilkan keseluruhan aset di CSIS Indonesia yang sebelumnya ada pada aplikasi akuntansi yang terinstall pada komputer milik bagian keuangan, pada saat ini aset tersebut hanya tercatat saat aset tersebut masuk dan saat aset tersebut sudah habis masa pakainya. 


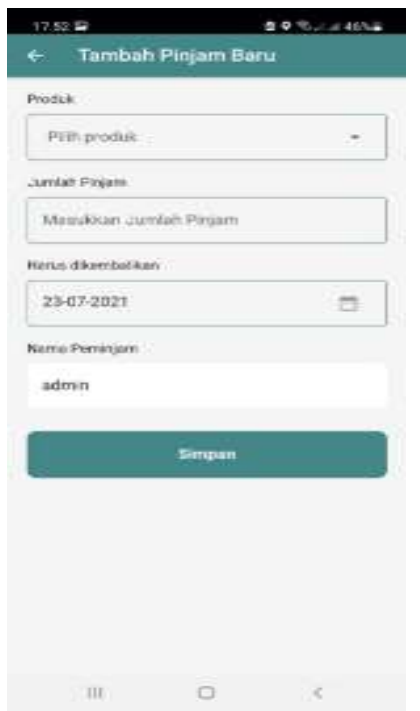

Gambar 4. Tampilan Halaman Peminjaman Barang

Gambar 4 di atas menunjukan form untuk melakukan peminjaman barang dimana sebelumnya, pencatatan peminjaman barang ini masih dilakukan manual menggunakan formulir yang dicetak lalu kemudian data yang tertulis tersebut dimasukan ke dalam file di program Microsoft excel.

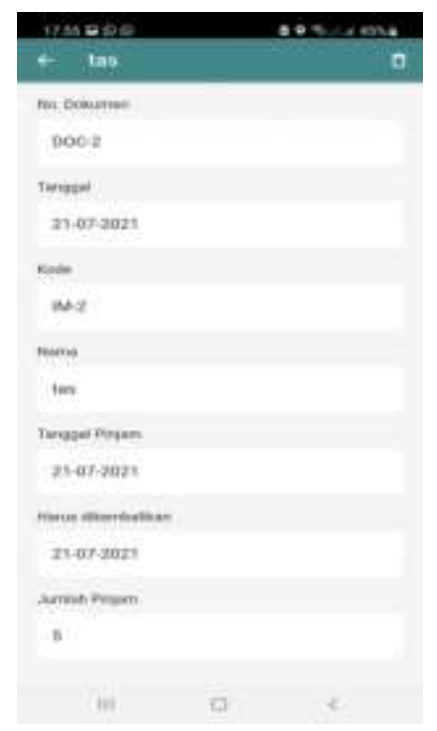

Gambar 5. Tampilan halaman detail peminjaman barang

Tampilan di atas merupakan halaman yang menampilkan form peminjaman barang dan detail peminjaman barang yang didalamnya tercatat nama barang yang akan dipinjam, tangggal peminjaman, tanggal seharusnya barang tersebut dikembalikan dan nama peminjam yang secara otomatis tertulis berdasarkan Username yang dimasukan pada gambar 2.

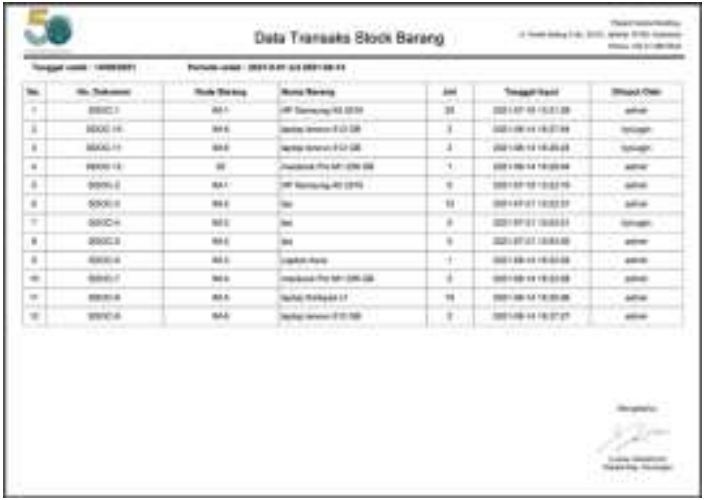

Gambar 6. Tampilan laporan daftar transaksi pada aplikasi

Tampilan di atas merupakan contoh laporan dari daftar transaksi yang terjadi di aplikasi pengelolaan aset yang sudah dibuat, laporan dibuat menjadi file PDF dengan cara aplikasi melakukan request ke server untuk kebutuhan laporannya seperti data transaksi atau jumlah barang yang yang masuk pada periode yang ditentukan oleh user, kemudian server merespon dengan melakukan redirect atau mengarahkan aplikasi ke URL untuk mengunduh laporan tersebut.

\section{SIMPULAN DAN SARAN}

Dengan dibuatnya sistem aplikasi pengelolaan aset ini, semua hal yang berhubungan dengan pengadaan produk, pencatatan peminjaman produk atau aset perusahaan dapat lebih mudah, cepat dan terdata dengan baik. Komputerisasi pada pengelolaan aset diharapkan dapat mempermudah aktivitas perusahaan terlebih jika membutuhkan data aset dan melakukan audit serta meminimalisir kehilangan atau aset yang tidak terdata.

Penulis sadar apa yang dilakukan belum sempurna mengingat keterbatasan yang dimiliki oleh penulis, namun aplikasi pengelolaan aset ini akan lebih baik jika bisa ditambahkan lebih banyak fitur seperti: Terintegrasi dengan program akunting yang saat ini digunakan. Akun yang ada bisa terhubung dengan akun lain seperti akun Microsoft atau Google dengan fungsi Oauth. Memiliki fitur pembaca barcode, sehingga lebih mudah untuk perekaman data. 
Penulis berharap aplikasi ini dapat berguna dan bisa membantu CSIS Indonesia dalam pengelolaan asetnya sehingga menjadi lebih baik lagi ke depannya.

\section{DAFTAR PUSTAKA}

Ahmad, A., \& Maulana, R. (2020). Perancangan Sistem Informasi Manajemen Aset Pada Pt. Acehlink Media Berbasis Android. Journal Informatic, Education And Management, 2(2).

Al- Bahra Bin Ladjamudin. (2013). Analisis Dan Desain Sistem Informasi. Graha Ilmu.

Antony Bryant. (2017). Grounded Theory And Grounded Theorizing.

App Annie. (2017). App Annie 2017 Retrospective Report. Https://Www.Appannie.Com/Downloa d/En/Insights/Market-Data/App-Annie2017-

Retrospective/1801_Report_2017_Retr ospective_EN.Pdf

Carmine Zaccagnino. (2020). Programming Flutter: Native, Cross-Platform Apps The Easy Way (M. Swaine, Ed.). The Pragmatic Programmers.

CSIS. (2016). Centre For Strategic And International Studies: Company Profile. CSIS.

David Wijaya, S. E. M. M. (2017). Manajemen Keuangan Konsep Dan Penerapannya.

Ikatan Akuntan Indonesia. (2011). ED PSAK 16 (Revisi 2011) Pernyataan Standar Akuntansi Keuangan. Www.Iaiglobal.Or.Id

Indrajani, S. Kom. , MM. (2011). Perancangan Basis Data dalam All in 1. PT. Elex Media Computindo.

Muchamad Nafi. (2019). Penetrasi Smartphone terhadap Jumlah Penduduk Indonesia.

https://databoks.katadata.co.id/datapubli sh/2019/07/05/penetrasi-smartphoneterhadap-jumlah-penduduk-indonesia 